\title{
To Find Out Prevalence of Various Ocular Manifestations and to Assess the Possible Aetiological Factors Including Psycho-Social and Hereditary Factors in Mentally Retarded Children
}

\author{
Vandana Misra', D.J. Pandey², B.D. Sharma², B.B. Maheshwari² \\ ${ }^{1}$ Assistant Professor, Department of Ophthalmology, Prasad Institute of Medical Sciences, Banthra, Lucknow, UP, India, ${ }^{2}$ Associate Professor, Department of \\ Opthalmology, S. N. Medical College, Agra, UP, India.
}

\section{Abstract}

Background: Children with disabilities are at a higher risk of visual impairment as compared to normal population. The present study was conducted to find out the prevalence of various ocular manifestations and to assess the possible aetiological factors including psycho-social and hereditary factors. Subjects and Methods: The present study was undertaken in the department of ophthalomology and paediatrics, S.N. Medical College, Agra. Two hundred and forty mentally retarded children between the ages of 3 months to 15 years of either sex were scrutinized to find out the prevalence of ocular manifestations in cases of mental retardation. A complete case history was taken. Results: In the present study, in 50\% cases, the cause of mental retardation could not be identified clinically. Causes of mental retardation which could be identified in our study were developmental cranial anomalies $-12.5 \%$, down's syndrome (7.5\%), post inflectional (6.7\%), congenital cerebral palsy $(5.8 \%)$, epilepsy (3.3\%), endocrine disorders, others $11.6 \%$. Out of these $66.7 \%$ were males and $33.3 \%$ cases were females. Ocular examination of the mentally retarded children revealed that $60 \%$ cases were having one or other form of ocular abnormalities. Strabismus $(30.5 \%)$ was the commonest ocular anomaly followed by refractive errors $(27.8 \%)$. Other ocular manifestations in order of frequency were congenital cataract (12.5\%), optic nerve disorders (7.5\%), lid and orbital abnormalities (5.5\%), nystagmus (2.7\%) and retinal disorders (1.4\%). Colour vision defects were found to be present in $13.2 \%$ mentally retarded children. Conclusion: The children with disabilities should undergo annual ophthalmic evaluation. We concluded from our study that visual function of the children should be assessed as soon as the child is admitted to the school. Earlier assessment and correction of the visual problems will have greater chance of achieving potential and will prevent unnecessary visual impairment.

Keywords: Disabilities, Visual Impairment, Ocular Manifestations.

Corresponding Author: Dr. Vandana Misra, Assistant Professor, Department of Ophthalmology, Prasad Institute of Medical Sciences, Banthra, Lucknow, UP, India.

Received: July 2019

Accepted: July 2019

\section{Introduction}

India has nearly 26.8 million people suffering from one or the other type of disability according to the census conducted in 2011. ${ }^{[1]}$ Vision plays a fundamental role in the acquisition of skills such as language, interpreting facial expressions, and skills requiring hand-eye coordination. If a child continues to have an uncorrected distance visual deficit beyond the age of 10-12 years, the plasticity of the visual system is lost and the recovery of vision can be limited. ${ }^{[2]}$ In children with disabilities other than visual disabilities, vision is one of the important senses which has more value for these children as they heavily depend on visual inputs for their understanding and communication with the outer world. ${ }^{[3,4]}$ The ocular problems in children with disabilities other than visual disabilities are often overlooked, as the main focus always remains on the primary disability. ${ }^{[5]}$ Additionally, the ocular examination in these children is a challenge and needs patience, skills and a broader range of assessment instruments. ${ }^{[4]}$ The present study was conducted to find out the prevalence of various ocular manifestations and to assess the possible aetiological factors including psycho-social and hereditary factors.

\section{Subjects and Methods}

The present study was undertaken in the department of ophthalomology and paediatrics, S.N. Medical College, Agra. Two hundred and forty mentally retarded children between the ages of 3 months to 15 years of either sex were scrutinized to find out the prevalence of ocular manifestations in cases of mental retardation.

\section{Selection of Cases:}

While selecting cases, special consideration was given to children with the history or observations of any of the following features which are usually associated with mental retardation: 
1. Delayed neuromuscular development and other milestones.

2. Convulsions and tremors.

3. Subnormal alertness and responsiveness to environment.

4. Irritability and restlessness.

5. Lack of concentration.

6. Learning problems.

7. Speech defects.

8. Defective hearing and/or vision.

9. Paresis and paralysis of muscles.

10. Emotional liability.

11. Abnormal behaviour and mannerism.

12. Teeth grinding and drooling

13. Abnormal psychological appearance.

These cases were assessed for their intellectual levels on the following intelligence tests:

1. Vineland Social Maturity Scale.

2. Seguin Form Board Test.

3. Stanford Binet test (Allahabad Hindi Version)

\section{Vineland Social Maturity Scale:}

This scale was administered to those children who were not able to take any test of intelligence. It consisted of social maturity graded in age levels in years, starting from $0-1$ to 25 years. The information given by the parent regarded social maturity was noted and level of social age was assessed.

\section{Seguin Form Board Test:}

This test consisted of 10 blocks of different shapes placed in a grooved board. For assessment of intelligence these blocks were removed in three piles (as the standard method). Three trail were given to the child to replace the block to it appropriate place. Time for each trail was recorded by the stop watch and corresponding to the shortest time taken his mental age was noted from table of norms. Subsequently I.Q. was calculated.

\section{Stanford Binet test:}

This test was originally constructed in 1905. It was adopted by the Bureau of Psychology, Allahabad in 1959. Indian adaptation of the test was used in the study. In this test, objects, pictures and drawing have been used largely at younger age. At older age levels, printed, verbal and numerical material have been used increasingly. The test was used in children above the age of two years. Mental age was calculated by adding the credits from the basal age upto the ceiling age.

A complete record of history and examination was made.

\section{Ocular Examination:}

\section{External Examination of the Eye:}

First of all a general examination was done in good illumination noting any obvious sign which may be present such as orbital deformity, skull deformity, facial asymmetry, ptosis, squint etc.

Most retardates exhibited unusually fine cooperation if they were not intimated or frightened. Whenever possible, a member of the child's family, preferably a parent was present to offer moral support. A few minutes invested in developing rapport with the child was amply rewarded during ensuing examination.

In most of the cases anterior segment of the eye was examined by using torch having good focus and corneal loupe, only a few cases when it was indicated, slit lamp examination was also supplemented.

\footnotetext{
Visual Acuity:

Visual acuity was measured by Standard Snellon's chart. The children who were unable to read the Snellen's chart, were given a white card on which a broken ring " $C$ " was drawn and were asked to indicate direction of selected broken ring.

For very young child and/or severely retarded child standard chart with calibrated hand pictures was used. The children were asked to indicate direction by pointing their hand or finger, up, down, right or left.

In toddlers and very retarded children vision was tested by response to toys of various sizes, recording the distance at which response was elicited.
}

\section{Ocular Motility:}

Ocular motility was tested simply by attracting the child's gaze in various directions. Movement of each eye individually (duction) and two eyes together (Version, conjugate movements) were assessed. Alignment was judged by symmetry of corneal light reflexes and by response to alternate occlusion of each eye.

\section{Colour Vision:}

Ishihara pseudoisochromatic plates were used to detect colour vision deficiency. In a room which lit adequately by day light, the plates were held at $75 \mathrm{~cm}$, from the mentally retarded children and tilted so that the plane of the paper was at right angle to line of vision. The numerals which are seen on plates 1-25 are stated and each answer should be given without more than 3 seconds delay.

In all subjects plates 26-38 covered with transparent tissue paper were also used and the binding lines between $2 \mathrm{X}$ 's were traced with soft camel brush. Tracing time for each plate was noted.

Type of colour deficiency with was read from the booklet provided with the ishihara pseudoisochromatic plates.

The patient should wear glasses if a refractive error exists.

\section{Examination of the Fundus:}

Both direct and indirect methods of ophthalmoscopy were used. Pupil was dilated with either of these mydriatics, 1 percent atropine ointment twice daily for 3 days, homatropine 2 percent or phenylephrine 5 percent or 10 percent eye drops. Children who were too young or uncooperative were sedated prior to ophthalmoscopic examination.

\section{Cycloplegic Refraction:}

Mentally retarded children with complaints of diminished vision and children with less visual acuity than normal having clear media were subjected to cycloplegic refraction. Atropine 1 percent eye ointment or drops three times a day for three days was prescribed and child was called on fourth 
day for refraction. Reflecting mirror retinoscope and streak retinoscope were used for refraction.

The mentally retarded children were studied during atleast two sessions. Durig the first session, an examination of the visual acuity, of the anterior segment and of the orthoptic status was performed. Prior to second session, the child's pupils were dilated with a cycloplegic agent so that during this session cycloplegic refraction and thorough fundoscopic examination was performed. If any further tests were required or if the child had been uncooperative, a third visit was scheduled.

A statistical analysis of the data was done to find out any correlation between the severity of mental retardation and ocular manifestations.

\section{Results}

Table 1: Prevalence of mental retardation according to gender

\begin{tabular}{|l|l|}
\hline Gender & \% \\
\hline Males & $66.7 \%$ \\
\hline Females & $33.3 \%$ \\
\hline
\end{tabular}

Table 2: Causes of mental retardation

\begin{tabular}{|l|l|}
\hline Causes of mental retardation & $\%$ \\
\hline $\begin{array}{l}\text { Developmental cranial anomalies } \\
\text { (Crouzen syndrome, Congenital hydrocephalous) }\end{array}$ & $12.5 \%$ \\
\hline Down's syndrome & $7.5 \%$ \\
\hline Post inflectional & $6.7 \%$ \\
\hline Congenital cerebral palsy & $5.8 \%$ \\
\hline Epilepsy & $3.3 \%$ \\
\hline $\begin{array}{l}\text { Endocrine Disorders } \\
\text { (Hypothroidism, Lurence Moon Beidi syndrome), } \\
\text { others (arachnodactyly, prematurity, muscular } \\
\text { dystrophy and albinism) }\end{array}$ & $11.6 \%$ \\
\hline Causes cannot be identified & $50 \%$ \\
\hline
\end{tabular}

Table 3: Prevalence of ocular manifestations

\begin{tabular}{|l|l|}
\hline Ocular manifestations & $\mathbf{\%}$ \\
\hline Strabismus & $30.5 \%$ \\
\hline Refractive errors & $27.8 \%$ \\
\hline Congenital cataract & $12.5 \%$ \\
\hline Optic nerve disorders & $7.5 \%$ \\
\hline Lid and orbital abnormalities & $5.5 \%$ \\
\hline Nystagmus & $2.7 \%$ \\
\hline Retinal disorders & $1.4 \%$ \\
\hline Colour vision defects & $13.2 \%$ \\
\hline
\end{tabular}

In the present study, in $50 \%$ cases, the cause of mental retardation could not be identified clinically. Causes of mental retardation which could be identified in our study were developmental cranial anomalies (Crouzen syndrome, Congenital hydrocephalous)-12.5\% , down's syndrome (7.5\%), post inflectional $(6.7 \%)$, congenital cerebral palsy (5.8\%), epilepsy (3.3\%), endocrine disorders (Hypothroidism, Lurence Moon Beidi syndrome), others (arachnodactyly, prematurity, muscular dystrophy and albinism) $11.6 \%$. Out of these $66.7 \%$ were males and $33.3 \%$ cases were females.

Ocular examination of the mentally retarded children revealed that $60 \%$ cases were having one or other form of ocular abnormalities.

Strabismus $(30.5 \%)$ was the commonest ocular anomaly followed by refractive errors (27.8\%). Other ocular manifestations in order of frequency were congenital cataract $(12.5 \%)$, optic nerve disorders $(7.5 \%)$, lid and orbital abnormalities $(5.5 \%)$, nystagmus $(2.7 \%)$ and retinal disorders $(1.4 \%)$.

Colour vision defects were found to be present in $13.2 \%$ mentally retarded children.

\section{Discussion}

Visual disorders are frequently seen in mentally retarded children. ${ }^{[6-8]}$ In the present study, in $50 \%$ cases, the cause of mental retardation could not be identified clinically. Causes of mental retardation which could be identified in our study were developmental cranial anomalies (Crouzen syndrome, Congenital hydrocephalous)-12.5\%, down's syndrome $(7.5 \%)$, post inflectional $(6.7 \%)$, congenital cerebral palsy $(5.8 \%)$, epilepsy (3.3\%), endocrine disorders (Hypothroidism, Lurence Moon Beidi syndrome), others (arachnodactyly, prematurity, muscular dystrophy and albinism) $11.6 \%$. Out of these $66.7 \%$ were males and $33.3 \%$ cases were females. Ocular examination of the mentally retarded children revealed that $60 \%$ cases were having one or other form of ocular abnormalities. Strabismus (30.5\%) was the commonest ocular anomaly followed by refractive errors $(27.8 \%)$. Other ocular manifestations in order of frequency were congenital cataract $(12.5 \%)$, optic nerve disorders (7.5\%), lid and orbital abnormalities (5.5\%), nystagmus $(2.7 \%)$ and retinal disorders $(1.4 \%)$. Colour vision defects were found to be present in $13.2 \%$ mentally retarded children.

Gogate $\mathrm{P}$ et al conducted a study and result showed that $61.4 \%$ were male. A total of $326(60 \%)$ had moderate-tosevere learning disabilities (IQs <50), and the mean IQ was 45.4. Two hundred and thirty-eight (45.3\%) had ocular disorder; $143(27.3 \%)$ had an uncorrected refractive error, followed by strabismus in $83(15.8 \%)$, nystagmus in 36 $(6.8 \%)$, optic atrophy in $34(6.5 \%)$, and congenital anomalies in $13(2.5 \%), 103$ children had more than one abnormality. Only 12 of the 143 students with refractive errors were using spectacles. A total of 132 (48.7\%) children with a history of perinatal insult had ocular problems. Ocular disorders were also common in those with a history of epilepsy, Down's syndrome, and cerebral palsy. ${ }^{[6]}$

Bankes found $49 \%$ mentally handicapped children had some form of refractive error. ${ }^{[9]}$

Warburg found the prevalence of myopia to be at $43 \%$ and of hypermetropia at $21 \%$ in severe/profoundly intellectually impaired adults. ${ }^{[10]}$

Van den Broek found refractive errors in $22 \%$ of adults with severe and profound multiple disabilities. ${ }^{[11]}$

Govind et al. found that overall $68 \%$ of children with cerebral palsy had ocular anomalies, refractive errors accounting for $28.5 \%$, strabismus $35.7 \%$, and optic atrophy for $10 \%$. $^{\text {[7] }}$

Strabismus and refractive errors were common in children with cerebral palsy according to two US studies. ${ }^{[12,13]}$ 


\section{Conclusion}

The children with disabilities should undergo annual ophthalmic evaluation. We concluded from our study that visual function of the children should be assessed as soon as the child is admitted to the school. Earlier assessment and correction of the visual problems will have greater chance of achieving potential and will prevent unnecessary visual impairment.

\section{References}

1. Punarbhava- National Interactive Portal on Disability- Census of India 2011 Data on Disability.

2. Susan Day. Normal and abnormal visual development. Section 1, chapter 2. In: Taylor D, editor. Pediatric ophthalmology. Oxford UK: Blackwell Science; 1997. p. 13-28.

3. Ostadimoghaddam H, Mirhajian H, Yekta AA, Rad DS, Heravian J, Malekifar A, et al. Eye problems in children with hearing impairment. J Curr Ophthalmol. 2015;27:56-59.

4. Gogate P, Soneji FR, Kharat J, Dulera H, Deshpande M, Gilbert C. Ocular disorders in children with learning disabilities in specia education schools of Pune, India. Indian J Ophthalmol. 2011;59:22328.

5. Salt A, Sargent J. Common visual problems in children with disability. Arch Dis Child.doi: $10.1136 / 2013 / 305267$.

6. Gogate P, Soneji FR, Kharat J, Dulera H, Deshpande M, Gilbert C, et al. Ocular disorders in children with learning disabilities in special education schools of Pune, India. Indian J Ophthalmol. 2011;59:223-8.

7. Govind A, Lamba PA. Visual disorders in cerebral palsy. Indian J Ophthalmol. 1988;36:88-91.

8. Katoch S, Devi A, Kulkarni P. Ocular defects in cerebral palsy. Indian J Ophthalmol. 2007;55:154-6.

9. Kennerley Bankes JL. The ophthalmologist's role in multidisciplinary assessment of developmentally handicapped children. Br J Ophthalmol 2006;90:1297-303

10. Warburg M. Visual impairment in adult people with moderate, severe, and profound intellectual disability. Acta Ophthalmol Scand 2001;79:450-4

11. Van den Broek EC, Janssen CG, Van Ramshorst T, Deen L. Visual impairments in peoples with severe and profound multiple disabilities: An inventory of visual functioning. J Intellect Disabil Res 2006;50:470-5.

12. Fantl EW, Pearlstein MA. Refractive errors in cerebral plasy. Am J Ophthalmol 1967;63:857-63.

13. Buckley E, Seaber JH. Dyskinetic strabismus as a sign of cerebral palsy. Am J Ophthalmol 1981;91:652-7.

Copyright: ( $\odot$ the author(s), 2019. It is an open-access article distributed under the terms of the Creative Commons Attribution License (CC BY 4.0), which permits authors to retain ownership of the copyright for their content, and allow anyone to download, reuse, reprint, modify, distribute and/or copy the content as long as the original authors and source are cited.

How to cite this article: Misra V, Pandey DJ, Sharma BD, Maheshwari BB. To Find Out Prevalence of Various Ocular Manifestations and to Assess the Possible Aetiological Factors Including Psycho-Social and Hereditary Factors in Mentally Retarded Children. Asian J. Med. Res. 2019;8(3):OT01-OT04.

DOI: dx.doi.org/10.21276/ajmr.2019.8.3.OT1

Source of Support: Nil, Conflict of Interest: None declared. 